UDC 81'255.2:316.77:[334.025:005.511

DOI https://doi.org/10.32841/2409-1154.2021.48-4.1

\author{
Aheicheva A. O., \\ PhD, \\ Dean of the Faculty of Humanities \\ National University "Yuri Kondratyuk Poltava Polytechnic"
} Rozhenko I. $\mathbf{V} .$,
Lecturer at the Department of Foreign Languages with Latin and Medical Terminology
Ukrainian Medical Stomatological Academy

Pshychkina N. H., Lecturer Poltava Applied Oil and Gas College of the National University "Yuri Kondratyuk Poltava Polytechnic"

Vypovska A. Ye.

\title{
ICT USAGE PECULIARITIES IN TRANSLATION
}

Summary. The article views the opportunities of information and communication technologies as a method for interpreters and translators' professional motivation formation. The main components of modern information technology in the translation business are studied: information and reference; accumulation, archiving, search and restoration tools of fragmented translations; formatting and conversion means of text data; translation texts localization means; tools for translation quality control. Main problems in translation are investigated and found out that the greatest problems in machine translation are associated with semantics, since the semantic constructions translation requires databases that are not currently developed in all online translation tools. In addition, translations of complex grammatical, syntactic and lexical structures cause considerable difficulties as well. The usage of information and computer technology in the translation process was explored. It is determined that it is important for a startup project translator to understand all the features of using the software, choose the appropriate programs or online tools and develop a strategy for the project translation process. The results of this work are very important and necessary for further study. A large amount of research is conducted in the field of statistical machine translation and machine translation based on examples. The article views the opportunities of information and communication technologies as a method for interpreters and translators' professional motivation formation. The article deals with the problem of computer technology application during the translation process. The article considers the state of professional translator ICT skills training in higher educational institutions. Owing to the need of adapting educational programs to the new global modernization requirements the problem and practical aspects of using ICT technologies in the process of professional translation using smart technologies and machine translation systems are analyzed. Main translation aspects using ICT is described in the article. Main peculiarities of ICT translation application is studied.

Key words: information and communication technologies, professional motivation.

Problem statement. Today innovations play a big role in the country's economy development, as well as in the globalization process around the world. In Ukraine, ICT usage in translation has increased in recent years. A translator is an important part in any team. The growth of the computer technology capabilities, establishing relations with foreign partners-investors, and the desire to bring an innovative solution to the world creates the preconditions for a large volume of technical documentation development, which must be translated into English and requires regular updates, adaptation, improvement, and localization. In these conditions, the issue of ICT usage in translation efficiency and quality becomes especially relevant.

The interest of linguists, as well as specialists in various science and technology fields to the ICT usage peculiarities in translation is constantly growing. This is also explained by the international integration and communication processes. The study of the peculiarities of the use of ICT as a tool to improve the quality and speed of the translation process is a relevant and promising area of modern linguistics.

Recent publications and research analyses. According to translation industry experts, if a translation contains a large number of errors, it may take as much time to finalize it as to translate a text from scratch, that is, without the help of appropriate computer programs. In this regard, the professional translators requirements for the quality of machine translation are much higher than those of non-professionals. These figures indicate that some translators are really interested in using automatic translation tools to increase labor productivity and reduce time costs.

Since machine translation requires subsequent editing by the translator, some researchers suggest optimizing this process [1-3].

The aim of the article. The aim of the study is to identify the modern ICT usage peculiarities in the translation.

Main material. Globalization has a tremendous impact on all knowledge areas and human activity types. It makes our life easier, but in many cases, complicates it as well. The ICT development contributes to more active international cultural contacts, intensification in all communication areas. Technological advances also stimulate the translation industry development. The growth of the computer technology capabilities and the transnational corporations number 
growth, the increasing products focus on consumers at the same time in a number of countries creates the preconditions for a large volume of technical documentation development, which must be translated into a significant number of languages and requires regular updates, adaptation, improvement, and localization. In these conditions, the issue of ICT usage in translation efficiency and quality becomes especially relevant.

The translators faced new tasks:

- large texts translation in a short time and without compromising the quality of translation;

- providing the Customer with a set of services for the translated documentation preparation for printing (formatting and layout of the text, including illustrations, diagrams);

- organization of effective and coordinated work of a specialists team involved in translation (translators, editors, specialists with subject area knowledge, quality specialists), planning and coordination of all work processes, project management;

- terminological and stylistic uniformity of all translated materials, as well as ensuring quality control at all translation stages and material preparation for printing [3].

Nevertheless, the information technology development has transformed the conditions the translator's work so much that the information volume processed during translation process, the aforementioned technical difficulties of the texts (terminology, the subject area specificity), the forced versatility of activities, the tendency to increase the translation speed put the modern translator in difficult conditions [4].

Today, computer technology helps to facilitate human life in many areas of its activities. It optimizes our work, helping to reduce both physical and intellectual costs.

There are software products and online services that belong to the field of so-called machine translation. These are all kinds of programs or websites that to some extent provide machine translation services. Machine translation is an action performed on a computer to convert text in one language into equivalent content in another language, as well as the result of such action [5].

At machine translation the following forms of computer and the human-translator interaction are possible:

- with post-editing (the source text is translated by the machine, and the human-translator edits the received result);

- with pre-editing (first, the person formatting the text for further processing by the machine. At the same time, it simplifies the text as much as possible, replacing complex words with synonyms and eliminating possible ambiguous readings);

- with interrediting (the source text is translated by the machine, but at the same time the human-translator interferes in its work and solves difficult cases);

- mixed systems.

In general, the machine translation scheme includes the following stages [6]:

1) source language text input into the computer;

2) its morphological analysis, the speech parts definitions and each word morphological characteristics;

3) syntactic analysis of each sentence in the source text (search for the main sentence members and determining syntactic connections types between them, expressed in the form of a tree of dependencies or a tree of direct components);

4) semantic analysis of each sentence, as a result of which a semantic representation of this sentence is created;
5) syntactic synthesis of sentences (sentences creation with the correct syntactic structure, corresponding to the source language rules and the type of syntactic sentence structure in translation language;

6) morphological synthesis of each word as part of individual sentences of the text (setting the words of the TL in the desired morphological forms);

7) the text output on the TL.

Machine translation has both obvious advantages and disadvantages [7].

The first advantage is the high translation speed. In just a few seconds, machine translation is ready. One do not have to spend hours flipping through dictionaries to translate each word or wasting time waiting for a translation from a professional translator.

The next advantage of machine translation is its relative low cost. There are many online translators who provide their services for free. While the professional translator services cost money.

Another machine translation advantage is accessibility. Anyone who has the Internet access or installs an offline machine translator's version can use it at any time from anywhere and receive a translation.

The fourth machine translation advantage is its versatility. Machine translators can usually translate text from almost any language into any other language. While professional translators most often specialize in one or more languages.

The main disadvantage of machine translation is its poor quality. Automatic translation services mostly translate text verbatim, without understanding the information and taking into account the context. They can convey the general essence of the text, however, they make lexical and grammatical errors. In some cases, the meaning of a single sentence or even the entire text may be completely distorted after translation [3].

Machine translation cannot consider context and decide how to deal with uncertain situations. While a professional translator can analyze the context and use his experience.

The word "automatic" is often used instead of the word "machine", which does not distort the meaning. However, the term "automated translation" has a different meaning. It is a programs complex that helps to translate texts, but does not perform the complete translation process instead of a human.

The translation industry around the world has grown several times over the past decade. The nature of the translator's work and the requirements for him have changed. First of all, the changes concerned the written translation of scientific and technical documentation.

In our opinion, the translator is also required to apply other important work skills in practice:

- knowledge of international standards for the design and translation of documentation for start-up projects to achieve the best result in localization;

- the right tone choice of information transfer in order to successfully convey the energy of the startup project team and their idea.

The professional image of the project in the international arena depends on the work of the translator.

If a translator fails, the following consequences may arise for a startup project:

- misunderstandings on the foreign partners and investors part, which may hinder the transaction in the future; 
- the wrong impression about the team representatives, which affects the repulsive image;

- poor translation quality (the translated phrases in the text do not sound familiar to the target language) may indicate that the project is not ready for launch.

The translation industry around the world has grown several times over the past decade. The nature of the translator's work and the requirements for him have changed. First of all, the changes concerned the written translation of scientific and technical documentation.

A competent translator, unlike a machine-translator, is guided by a large number of criteria when choosing a foreign language equivalent. These include not only the meaning of each word and the meaning of the grammatical constructions used, but also the concept of the value, novelty of the information offered, the possibility of compressing information, using standard formulas, clichés. A professional translator can, depending on the audience of listeners or readers to whom the translation is intended, make corrections, clarifications, substitutions in the translation text, and also maintains a style of presentation defined for a particular genre, builds equivalents of terms that are not in dictionaries.

Possession of information technologies and automated translation tools is an important component of translation competence, including linguistic, communicative, extralinguistic, text-forming and other competencies.

The use of Internet technologies greatly facilitates the work of the translator and saves time, allows to speed up the process of exchanging information, and quickly resolve emerging problems in the translated text. However, none of the existing electronic programs is capable of providing high-quality translation without the participation of a human translator, which makes it relevant to training in translation for representatives of various professional fields.

Thus, it can be concluded that computer translation systems make a significant number of errors. Nevertheless, MT based on neural networks have significantly fewer errors. The analysis shows that at the moment the Google system provides the most adequate and equivalent version of the translation, but nevertheless there are still problems with the translation of rare words and terms among them, as well as the mismatch between the number of words of the original and translation affects the meaning.

Some conclusions about the ICT usage in the translation are displayed. It is highlighted the following disadvantages of computer translation that require human correction:

- lack of meaning in individual sentences;

- wrong translation choice of some ambiguous words;

- incorrect word order;

- disagreement between the sentence parts.

At the same time, we note the advantages of machine translation:

- it is time-saving;

- correct translation of individual parts of the text;

- general text meaning conveying.

The main components of modern information technology in the translation business should primarily include: information and reference; accumulation, archiving, search and restoration tools of fragmented translations; formatting and conversion means of text data; translation texts localization means; tools for translation quality control.
Our online-translators analysis showed that at the moment the Google system provides the most adequate and equivalent version of the translation, but nevertheless there are still problems with the translation of rare words and terms among them, as well as the mismatch between the number of words of the original and translation affects the meaning. Thus, it can be concluded that computer translation systems make a significant number of errors.

On this basis, it is concluded that computer translation systems are developing very rapidly and their further development is associated with the continuation of careful consideration of the context and topics. That is why today the study of texts translation performed using computer translation systems is one of the most promising areas of linguistic research. It allows to develop algorithms for translator work at the stage of post-editing scientific and technical text, received after MT.

Further development of automatic translation is associated with the possibility of a holistic assessment of texts made with the help of computer translation systems. It is an adequate and complete assessment that will help to identify and systematize all the shortcomings of the program so that in the future these problems are resolved.

Conclusions. Expansion of international cooperation makes the problem of business proposals and contracts, prompt translation of correspondence, etc. especially applicable. The creation and development of automatic machine translation systems, which could become an essential tool in the work of specialists of various profiles can be one of the best solutions to this problem.

The possibility of automating such seemingly routine mental work as translation has been attracting attention for a long time. Machine translation has undergone significant changes over the past few years. A large amount of research is conducted in the field of statistical machine translation and machine translation based on examples.

The professional translators' requirements for the machine translation quality are much higher than those of non-professionals. These figures indicate that some translators are really interested in using automatic translation tools to increase labor productivity and reduce time costs. At the present time, new programs are constantly appearing, the already known ones are being updated or radically revised.

\section{References:}

1. DePalma D. Business without Borders. A Strategic Guide to Global Marketing. New York : John Wiley \& Sons, Inc., 2002. 267 p.

2. Esselink B. A Practical Guide to Localization. Amsterdam/ Philadelphia : John Benjamins Publishing Company, 2000. 488 p.

3. Esselink B. A Practical Guide to Software Localization. Amsterdam/ Philadelphia : John Benjamins Publishing Company, 1998. 309 p.

4. Hutchins J.H. Somers: An Introduction to Machine Translation. London : Academic Press, 1992. 362 p.

5. Lagoudaki E. The Value of Machine Translation for the Professional Translator. URL: https://www.aclweb.org/anthology/2008.amtasrw.4.pdf.

6. Yunker J. Strategies. Boston ; Indianapolis ; London ; New York ; San Francisco : New Riders, 2003. 552 p.

7. Kay M. The Proper Place of Men and Machines in Language Translation. Machine Translation. 1997. Vol. 12. P. 3-23. 
Агейчева А. О., Роженко І. В., Пшичкіна Н. Г., Виповська А. С. Особливості застосування IКТ в перекладі

Анотація. Компетенція перекладу включає лінгвістичну, комунікативну, текстоформувальну, технічну компетентність, а також особистісні характеристики перекладача. Перекладач повинен не лише добре орієнтуватися та розуміти тематичний словник, а й застосовувати інші важливі навички роботи на практиці.

Зроблено грунтовні висновки щодо використання IКТ під час перекладу. Виділено такі недоліки комп’ютерного перекладу, які вимагають корекції людиною: а) відсутність значення в окремих реченнях; б) неправильний вибір перекладу деяких багатозначних слів; в) неправильний порядок слів; г) неузгодження частин речення.

Водночас виокремлено й переваги машинного перекладу, зокрема: а) економія часу; б) правильний переклад окремих частин тексту; в) передання загального змісту тексту.

Основні компоненти сучасних інформаційних технологій у перекладацькому бізнесі повинні включати насамперед загальну та довідкову інформацію, інструменти накопичення, архівування, пошуку й відновлення фрагментованих перекладів, засоби форматування та перетворення текстових даних, засоби локалізації текстів перекладів, інструменти для контролю якості перекладу.

Аналіз онлайн-перекладачів показав, що на цей час система Google надає найбільш адекватну та еквівалентну версію перекладу, однак ще спостерігаються проблеми 3 перекладом деяких слів і термінів, а також невідповідність між кількістю слів оригіналу та перекладом, що впливає на значення. Тому можна констатувати, що системи комп'ютерного перекладу допускають значну кількість помилок.

На підставі аналізу зроблено висновок, що системи комп'ютерного перекладу розвиваються дуже швидко, їх подальший розвиток пов'язаний із продовженням грунтовного розгляду контексту та тем. Ось чому сьогодні вивчення перекладу текстів, що виконується за допомогою комп'ютерних систем перекладу, $\epsilon$ одним із найбільш перспективних напрямів лінгвістичних досліджень. Це дає змогу розробити алгоритми роботи перекладача на етапі постредагування науково-технічного тексту, отриманого після машинного перекладу. У статті описані основні аспекти перекладу з використанням ІКТ. Вивчено основні особливості застосування ІКТ-перекладу.

Ключові слова: інформаційно-комунікаційні технологіï, професійна мотивація. 